\title{
TNF alpha Promoter Polymorphism May Confer Susceptibility to Rheumatoid Arthritis and Influence TNF alpha Production but not the Clinical Phenotype and Treatment Response
}

Christina Mary Mariaselvam ${ }^{1,2}$, Salah Sofiane ${ }^{2}$, Wahid Boukouaci ${ }^{2}$, Catherine Fortier ${ }^{3}$, Dominique Charron ${ }^{2,3}$, Rajagopal Krishnamoorthy ${ }^{2}$, Ryad Tamouza ${ }^{2,3}$ and Vir Singh Negi ${ }^{*}$

${ }^{1}$ Department of Clinical Immunology, Jawaharlal Institute of Postgraduate Medical Education and Research (JIPMER), Pondicherry- 605 006, India

2INSERM, UMRS, U1160, Saint Louis Hospital, Paris, F75010, France

${ }^{3}$ Jean Dausset laboratory of Immunology and Immunogenetics and LabEx Transplantex, Saint Louis Hospital, Paris, F75010, France

*Corresponding authors: Vir S. Negi, Department of Clinical Immunology, Jawaharlal Institute of Postgraduate Medical Education and Research (JIPMER), Pondicherry - 605006, India,Tel: +91 4132297358 , +91 9443433974; Fax: +91 2272067; E-mail: vsnegi22@yahoo.co.in Christina Mary Mariaselvam, Jean Dausset laboratory of Immunology and Immunogenetics and LabEx Transplantex, Saint Louis Hospital, Paris, F75010, France, Tel: 33142499293; E-mail: christina.mariaselvam@gmail.com

Rec date: Nov 24, 2014; Acc date: Dec 22, 2014; Pub date: Dec 28, 2014

Copyright: (c) 2014 Mariaselvam CM, et al. This is an open-access article distributed under the terms of the Creative Commons Attribution License, which permits unrestricted use, distribution, and reproduction in any medium, provided the original author and source are credited.

\begin{abstract}
Rheumatoid arthritis (RA) is characterized by progressive joint damage predominantly mediated by proinflammatory molecules including the tumor necrosis factor alpha (TNF- $\alpha$ ). Several studies have addressed the relationship between diversity of TNF- $\alpha$ gene and susceptibility to RA and its clinical phenotypes but the results have been inconsistent. We conducted a case-control study to analyze the potential influence of three functionally relevant TNF- $\alpha$ promoter variants on RA incidence and disease phenotypes and serum TNF- $\alpha$ levels in a genetically homogeneous south Indian Tamil population. Genomic DNA from 269 RA patients and 233 healthy controls (HC) were analyzed by TaqMan 5'-nuclease assay for the distribution of the following SNPS: TNF-a -857 C $>$ T ( $r$ 1799724), TNF- $\alpha-308 \mathrm{G}>\mathrm{A}$ (rs1800629) and TNF- $\alpha-238 \mathrm{G}>\mathrm{A}$ ( $r$ s 361525). We found that the frequency of the TNF- $\alpha-238$ GG genotype and G allele was higher in patients as compared to controls [Pc: 0.004, OR: 2.01, Cl 95\%: 1.23-3.29 and Pc: 0.004, OR: 1.89 , Cl 95\%: 1.22-2.97 respectively]. The genotype and allele frequency of TNF-a -857 C>T and -308 G>A polymorphisms did not differ between patients and controls. Haplotype analysis revealed that the frequency of ancestral TNF- $\alpha(-857,-308,-238)$ C-G-G haplotype was more in patients than in HC (80\% vs $74 \%, \mathrm{P}: 0.03$, OR: $1.39, \mathrm{Cl} 95 \%$ : 1.02-1.89). The CGA haplotype was found at a higher frequency in $\mathrm{HC}$ than in patients $(10.6 \%$ vs $7 \%$, P: 0.03 , OR: 0.61 , Cl $95 \%$ : $0.38-0.96)$. We also found that TNF- $\alpha-857 T$ allele was associated with significantly high titers of circulating TNF- $\alpha$. Our data suggest that TNF- $\alpha-238$ G allele, -238 GG genotype and the TNF- $\alpha-C-G-G$ ancestral haplotype may be associated with susceptibility to RA. In addition, the TNF- $\alpha-857 \mathrm{C}>\mathrm{T}$ variant might influence the TNF- $\alpha$ production.
\end{abstract}

Keywords: Rheumatoid Arthritis; Serum TNF- $\alpha$ level; South Indian Tamils; TNF- $a$ haplotype; TNF- $\alpha$ promoter polymorphism

\begin{abstract}
Abbreviations:
ACPA: Anti-Citrullinated Peptide Antibodies; ACR: American College of Rheumatology; DMARDs: Disease Modifying AntiRheumatic Drugs; EULAR: European League Against Rheumatism; HCQ: Hydroxychloroquine; HLA: Human Leukocyte Antigen; MHC: Major Histocompatibility Complex; MTX: Methotrexate; RA: Rheumatoid Arthritis; RF: Rheumatoid Factor; SNPs: Single Nucleotide Polymorphisms; SSZ: Sulphasalazine; TNF- $\alpha$ : Tumor Necrosis Factor alpha; YORA: Young Onset RA
\end{abstract}

\section{Introduction}

Rheumatoid arthritis (RA) is a chronic inflammatory disease that leads to progressive joint damage and destruction. It is characterized by synovial inflammation and hyperplasia. The rheumatoid synovial lining contains activated $\mathrm{B}$ and $\mathrm{T}$ cells, plasma cells, macrophages, neutrophils and natural killer (NK) cells [1]. These immune cells mediate inflammation through excessive cytokine (TNF- $\alpha$, IL-1 $\beta$, IL-6,
IL-7, IL-12, IL-15, IL-18, IL-23p19 and TGF- $\beta$ ) production driven by cell-cell interaction in the inflamed joint $[2,3]$.

Tumor necrosis factor alpha (TNF- $\alpha$ ), a pro-inflammatory cytokine plays a key role in the pathogenesis of RA. It is overproduced in inflamed synovium by macrophages, NK cells and other immune cells. TNF- $\alpha$ stimulates secretion of other cytokines (IL-1 and IL-6), induces production and release of chemokines (RANTES, MCP-1, IL-8 and SDF-1) that attract leucocytes to the synovium and activates endothelium through up regulation of adhesion molecules (E selectin, VCAM-1). It induces and maintains Human Leukocyte Antigen (HLA) class II expression on immune cells and has co-stimulatory effect on $\mathrm{T}$ cell activation and antibody production by $\mathrm{B}$ cells [1]. Chondrocyte activation by TNF- $\alpha$ induces proteolytic and metalloproteinase enzymes leading to cartilage destruction. Osteoclast activation results in bone resorption and destruction of subchondral bone.

TNF- $\alpha$ transgenic mice develop arthritis similar to RA [4]. High concentration of TNF- $\alpha$ are found in the plasma, synovial fluid and synovial tissue of patients with RA [1,3]. Anti-TNF therapy dramatically improves arthritis in these patients [5]. Thus, TNF- $\alpha$ gene 
Citation: Mariaselvam CM, Sofiane S, Boukouaci W, Fortier C, Charron D, et al. (2014) TNF alpha Promoter Polymorphism May Confer Susceptibility to Rheumatoid Arthritis and Influence TNF alpha Production but not the Clinical Phenotype and Treatment Response. J Mol Biomark Diagn 5: 206. doi:10.4172/2155-9929.1000206

Page 2 of 6

may be a susceptibility gene for RA as well as a genetic modifier of disease phenotype including response to therapy.

The TNF locus located within HLA class III region of the major histocompatibility complex (MHC) has been extensively studied and found to be associated with the genetic susceptibility to immune mediated disorders including infection, autoimmunity and cancers. Many single nucleotide polymorphisms (SNPs) have been identified in the promoter region of TNF- $\alpha$ gene [6]. Of these, -238 (rs361525), -308 (rs1800629) and -857 (rs1799724) comprising the common ancestral haplotype in Caucasians are the most studied $[7,8]$. Functional studies of TNF- $\alpha$ polymorphism have indicated its association with different TNF- $\alpha$ expression profiles and circulating TNF- $\alpha$ levels [9-11]. These polymorphisms in TNF- $\alpha$ promoter region may influence TNF- $\alpha$ production, which in turn may have an impact on inflammatory responses, disease expression and response to therapy.

Available data on association of TNF- $\alpha$ promoter polymorphism with RA is controversial. A number of SNPs in this region are reported to be associated with susceptibility to RA and its clinical phenotypes in different populations [12-18]. The reported relationship between TNF- $\alpha$ polymorphism and response to anti-TNF therapy is also inconsistent $[19,20]$.

There is limited information on the prevalence of RA from India. The reported prevalence ranges from $0.55 \%$ to $0.75 \%$, similar to that reported from the developed countries but higher than reported from other Asian countries including China, Indonesia and Philippines $[21,22]$. The only study that addressed the potential influence of the TNF- $\alpha-308 \mathrm{G}>\mathrm{A}$ and $-863 \mathrm{C}>\mathrm{A}$ polymorphisms is from North India [14]. This study observed that TNF- $\alpha-308 \mathrm{~A}$ allele conferred protection against RA while TNF- $\alpha-863 \mathrm{~A}$ had weak association with early onset disease in females.

Taking advantage of a phenotypically well-defined and ethnically homogeneous South Indian Tamil RA population of Dravidian descent, we conducted a case-control study to analyze whether three functionally relevant TNF- $\alpha$ promoter SNPs i.e. TNF- $\alpha-857,-308$ and -238 could influence RA susceptibility, disease phenotype, TNF- $\alpha$ production or response to therapy with synthetic disease modifying anti-rheumatic drugs (DMARDs).

\section{Materials and Methods}

\section{Study design}

This was a case control immunogenetic study conducted at the Jawaharlal Institute of Post graduate Medical Education and Research (JIPMER), Puducherry a major tertiary referral center in South India.

\section{Study subjects}

Patients diagnosed with RA, on the basis of 2010modified American College of Rheumatology Criteria (ACR) [23] from ethnic Tamil South Indian population, were recruited for the study. A total of 269 patients (245 females and 24 males) were enrolled. Patients with inactive disease or other co-morbid conditions were excluded. The mean age of patients at enrolment was $41.2 \pm 10.9$ years (range 18-72 yrs.) and age of onset was $37.7 \pm 11.4$ yrs. (range 17-72 yrs.). Among the 269 patients, 159 (59\%) had erosive/deforming disease and 57 (21\%) extraarticular manifestations. Rheumatoid Factor (RF) and Anti Citrullinated Peptide Antibodies (ACPA) were present in 201 (75\%) and $160(60 \%)$ patients respectively. All patients received methotrexate (MTX) as initial therapy up to a maximum of $25 \mathrm{mg}$ per week. In case of inadequate response, sulphasalazine (SSZ) and hydroxychloroquine (HCQ) with or without low dose prednisolone ( $<7.5 \mathrm{mg}$ per day) were added. Treatment response was assessed using EULAR response criteria [24] at the end of six month or after 8 continuous weeks of stable combination DMARD therapy whichever was later. A total of 233 unrelated healthy individuals ( 201 females and 32 males) without family history of autoimmune disorders were included as healthy controls (HC). The HC group was age-, sex- and ethnicity-matched with the patient subset. Written informed consent was obtained from all study participants before enrolment. The study was reviewed and approved by the Institution Ethics Committee.

\section{Autoantibody measurement}

IgM RF in the serum of the patients was measured by Nephelometry (Seimens Health Care, Marburg, Germany N Prospec ${ }^{\oplus}$, Dade Behring, Germany) using kits supplied by Siemens Healthcare Diagnostics Inc., (Marburg, Germany). RF titers above $10 \mathrm{IU} / \mathrm{ml}$ were considered positive. ACPA status was determined by sandwich ELISA method using a second-generation commercial ELISA kit (Biosystems, Barcelona, Spain). Patients with ACPA values above $15 \mathrm{IU} / \mathrm{ml}$ were labeled as ACPA-positive.

\section{Serum TNF- $\alpha$ measurement}

The serum level of TNF- $\alpha$ was quantified using a sandwich ELISA kit according to the manufacturer's instructions (Ani Biotech Oy, Finland) and the standard curves established in our laboratory. TNF- $\alpha$ levels up to $23.4 \mathrm{pg} / \mathrm{ml}$ were considered to be 'low titers' and those above were considered 'high titers'.

\section{DNA extraction}

Genomic DNA from patients and controls was extracted from the peripheral blood leukocytes using standard protocol. The quality and quantity of DNA was analyzed by spectrophotometry (Nanodrop, Thermoscientific, USA).

\section{TNF-a genotyping}

Three SNPs in the TNF- $\alpha$ promoter region, at positions -857 (rs1799724), -308 (rs1800629) and -238 (rs361525) were genotyped using TaqMan 5'-nuclease assay with allele specific fluorogenic probes. PCR amplification was performed in $10 \mu$ l volume containing $50 \mathrm{ng}$ of DNA under the following PCR conditions: $50^{\circ} \mathrm{C}$ for $2 \mathrm{~min}, 95^{\circ} \mathrm{C}$ for 10 min, 50 cycles of $95^{\circ} \mathrm{C}$ for $15 \mathrm{sec}$ and $60^{\circ} \mathrm{C}$ for $1 \mathrm{~min}(\mathrm{rs} 1799724$, rs 361525 ) and $50^{\circ} \mathrm{C}$ for $2 \mathrm{~min}, 95^{\circ} \mathrm{C}$ for $10 \mathrm{~min}, 50$ cycles of $95^{\circ} \mathrm{C}$ for $15 \mathrm{sec}$ and $60^{\circ} \mathrm{C}$ for $1.30 \mathrm{~min}$ (rs800629). The amplification was carried out in SteponePlusTM real time PCR system (Applied Biosystems, USA).

\section{Statistical analysis}

Allele and genotype frequencies of the studied SNPs were compared between patients and controls using Chi square test with Yates correction. P value less than 0.05 was considered significant. Both odds ratio $(\mathrm{OR})$ and $95 \%$ confidence interval $(95 \% \mathrm{CI})$ were calculated to assess the relative risk conferred by a specific allele or genotype. Gender, age of onset, disease activity, erosive/deforming disease, extraarticular manifestations, autoantibody (RF, ACPA) positivity and 
Citation: Mariaselvam CM, Sofiane S, Boukouaci W, Fortier C, Charron D, et al. (2014) TNF alpha Promoter Polymorphism May Confer Susceptibility to Rheumatoid Arthritis and Influence TNF alpha Production but not the Clinical Phenotype and Treatment Response. J Mol Biomark Diagn 5: 206. doi:10.4172/2155-9929.1000206

Page 3 of 6

response to DMARDs were the characteristics included in the analysis. Deviation from Hardy-Weinberg equilibrium was analyzed using $\chi^{2}$ testing. Continuous variables were compared by Student's 2-tailed $t$ test. The statistical software GraphPadInStat was used for carrying out the statistical analysis. Haplotype and linkage disequilibrium (LD) analysis between the three SNPs was performed with Haploview program v. 4.2. (www.broadinstitute.org/haploview). The Lewontin's D' measure was used to estimate the inter marker coefficient of linkage disequilibrium. Two markers with a D' value more than 0.7 were defined to be in the same haplotype block.

\section{Results}

\section{Association of TNF- $\alpha$ promoter polymorphism with genetic susceptibility to RA}

For the studied polymorphisms, the observed genotype distribution satisfied the expected Hardy-Weinberg proportions for both patient and control samples and overall frequencies were comparable to those previously published in public database (http:// www.ncbi.nlm.nih.gov/). We found that the distribution of the TNF- $\alpha$ $-238 \mathrm{G}$ allele and GG genotype was higher in patients as compared to healthy controls ( $\mathrm{G}$ vs $\mathrm{A}$ : $93 \%$ vs $87 \%, \mathrm{Pc}=0.004, \mathrm{OR}=1.89,95 \% \mathrm{CI}=$ $1.21-2.97$ and GG vs $\mathrm{GA}+\mathrm{AA}: 87 \%$ vs $76 \%, \mathrm{Pc}=0.004, \mathrm{OR}=2.01$, $95 \% \mathrm{CI}=1.23-3.29$ in patients and healthy controls respectively) (Table 1). We did not observe any association between the frequency of alleles and genotypes of the other two SNPs and RA.

\begin{tabular}{|c|c|c|c|}
\hline TNF- $\alpha-857$ & RA, $n=269(\%)$ & $H C, n=233(\%)$ & Pc OR $(95 \% \mathrm{Cl})$ \\
\hline $\mathrm{CC}$ & 78 & 75 & NS \\
\hline $\mathrm{CT}+\mathrm{TT}$ & 22 & 25 & NS \\
\hline C & 88 & 87 & NS \\
\hline $\mathrm{T}$ & 12 & 13 & NS \\
\hline \multicolumn{4}{|l|}{ TNF- $\alpha-308$} \\
\hline GG & 97 & 94 & NS \\
\hline$A G+A A$ & 3 & 6 & NS \\
\hline G & 98 & 97 & NS \\
\hline A & 2 & 3 & NS \\
\hline \multicolumn{4}{|l|}{ TNF- $\alpha-238$} \\
\hline GG & 87 & 76 & $0.004 \quad 2.01(1.23-3.29)$ \\
\hline$G A+A A$ & 13 & 24 & $0.003 \quad 0.48(0.29-0.79)$ \\
\hline G & 93 & 87 & $0.004 \quad 1.89(1.21-2.97)$ \\
\hline A & 7 & 13 & $0.004 \quad 0.53(0.34-0.82)$ \\
\hline
\end{tabular}

Table 1: Genotype and allele frequency of TNF- $\alpha$ promoter polymorphism in RA and HC

Haplotype re-construction revealed three major TNF-a haplotypes (frequency $>5 \%$ ), of which the ancestral C-G-G haplotype consistently reported to be associated with RA, was found at a higher frequency in patients as compared to $\mathrm{HC}(80 \%$ vs $74 \%, \mathrm{P}=0.03, \mathrm{OR}=1.39$, $95 \% \mathrm{CI}=1.02-1.89)$. Conversely the C-G-A haplotype was found to be more frequent in healthy controls than in patients $(10.6 \%$ vs $7 \%$, $\mathrm{P}=0.03, \mathrm{OR}=0.61,95 \% \mathrm{CI}=0.38-0.98$ ) (Table 2). We also found that the TNF rs1799724 and rs361525 were in strong linkage disequilibrium (Figure 1).Color scheme of the LD map is based on the standard D'/LOD option in the Haploview software. Dark squares indicate high $\mathrm{r} 2$ and light squares indicate low r2 values. Values in squares are the D' between single markers.

\section{Association of TNF- $\alpha$ promoter polymorphism with RA clinical and biological phenotypes}

We observed that the studied TNF- $\alpha$ promoter polymorphisms did not influence clinical phenotype, autoantibody production or response to treatment with DMARDs. We further explored the influence of these polymorphisms on TNF- $\alpha$ production by measuring serum TNF- $\alpha$ levels and found that the TNF- $\alpha-857 \mathrm{~T}$ allele was more prevalent in patients with high titers of serum TNF- $\alpha$ and the $C$ allele with low titers of TNF- $\alpha$ in all patients with RA, in female and young onset subgroups of RA (YORA) (Table 3). 
Citation: Mariaselvam CM, Sofiane S, Boukouaci W, Fortier C, Charron D, et al. (2014) TNF alpha Promoter Polymorphism May Confer Susceptibility to Rheumatoid Arthritis and Influence TNF alpha Production but not the Clinical Phenotype and Treatment Response. J Mol Biomark Diagn 5: 206. doi:10.4172/2155-9929.1000206

Page 4 of 6

\begin{tabular}{|l|l|l|l|l|}
\hline $\begin{array}{l}\text { Haplotype } \\
\mathbf{( 1 - 2 - 3 )}\end{array}$ & RA, $\mathbf{n = 5 3 8}$ (\%) & $\begin{array}{l}\text { HC, } \mathbf{n = 4 6 4} \\
\mathbf{( \% )}\end{array}$ & $\mathbf{P}$ & OR (95\% Cl) \\
\hline C-G-G & 80 & 74 & 0.03 & $\begin{array}{l}1.39(1.02-1.8 \\
9)\end{array}$ \\
\hline T-G-G & 11 & 10.6 & NS & \\
\hline C-G-A & 7 & 10.6 & 0.03 & $\begin{array}{l}0.61(0.38-0.9 \\
8)\end{array}$ \\
\hline C-A-G & 1.6 & 1.7 & NS & \\
\hline T-G-A & 0.4 & 1.7 & 0.03 & $\begin{array}{l}0.21 \\
(0.02-1.08)\end{array}$ \\
\hline T-A-G & 0 & 0.9 & 0.03 & $\begin{array}{l}0.00 \\
(0.00-1.30)\end{array}$ \\
\hline C-A-A & 0 & 0.4 & NS & \\
\hline $\begin{array}{l}\text { 1-rs1799724, 2-rs1806629, 3- rs361525, RA-Rheumatoid Arthritis, HC- Healthy } \\
\text { control, OR- odds ratio, 95\% Cl -95\% confidence interval, P values <0.05 were } \\
\text { considered significant. }\end{array}$ & \multicolumn{5}{|l}{} \\
\hline
\end{tabular}

Table 2: Frequency of TNF- $\alpha$ haplotypes in RA and HC

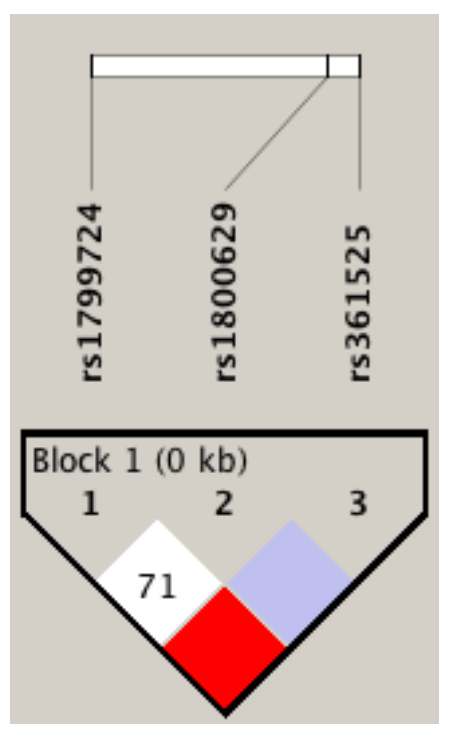

Figure 1: Linkage disequilibrium block in the promoter region of TNF- $\alpha(-857,-308,-238)$.

\begin{tabular}{|l|l|l|l|l|l|}
\hline $\begin{array}{l}\text { TNF- } \\
\mathbf{\alpha}-857\end{array}$ & $\begin{array}{l}\text { High titers } \\
(\%)\end{array}$ & Low titers (\%) & $\mathbf{P}$ & Pc & OR (95\% Cl) \\
\hline Total RA & $\mathrm{n}=28$ & $\mathrm{n}=230$ & & & \\
\hline CC & 64 & 79.6 & 0.07 & $\mathrm{NS}$ & \\
\hline CT+TT & 36 & 20.4 & 0.07 & $\mathrm{NS}$ & \\
\hline $\mathrm{C}$ & 79 & 89 & 0.02 & $\begin{array}{l}0.0 \\
3\end{array}$ & $0.44(0.21-0.97)$ \\
\hline $\mathrm{T}$ & 21 & 11 & 0.02 & $\begin{array}{l}0.0 \\
3\end{array}$ & $2.29(1.03-4.78)$ \\
\hline
\end{tabular}

\begin{tabular}{|l|l|l|l|l|l|}
\hline $\begin{array}{l}\text { Female } \\
\text { RA }\end{array}$ & $\mathrm{n}=26$ & $\mathrm{n}=207$ & & \\
\hline CC & 65 & 80.8 & 0.07 & $\mathrm{NS}$ & $0.45(0.18-1.24)$ \\
\hline CT+TT & 35 & 19.2 & 0.07 & $\mathrm{NS}$ & \\
\hline $\mathrm{C}$ & 79 & 90 & 0.02 & $\begin{array}{l}0.0 \\
3\end{array}$ & $0.41(0.19-0.95)$ \\
\hline T & 21 & 10 & 0.02 & 0.0 & $2.44(1.05-5.30)$ \\
\hline YORA & $\mathrm{n}=28$ & $\mathrm{n}=216$ & 3 & \\
\hline CC & 64 & 81 & 0.05 & $\mathrm{NS}$ & \\
\hline CT+TT & 36 & 19 & 0.05 & $\mathrm{NS}$ & \\
\hline C & 79 & 90 & 0.01 & $\begin{array}{l}0.0 \\
2\end{array}$ & $0.41(0.19-0.91)$ \\
\hline T & 21 & 10 & 0.01 & $\begin{array}{l}0.0 \\
2\end{array}$ & $2.47(1.10-5.20)$ \\
\hline RA: Rhe & & & & & \\
\hline
\end{tabular}

RA: Rheumatoid Arthritis, HC: Healthy Controls, OR: Odds ratio, 95\% Cl: $95 \%$ confidence interval, YORA: Young Onset RA (onset below 55 years of age). $\mathrm{Pc}<0.05$ is considered significant.

Table 3: Influence of TNF- $\alpha$ promoter polymorphism on the serum TNF-a levels

\section{Discussion and Conclusion}

In the present study involving South Indian Tamil patients with RA, we analyzed the distribution of three functionally relevant SNPs of the TNF- $\alpha$ promoter region and found that both the TNF- $\alpha-238 G G$ genotype and the C-G-G ancestral haplotype were associated with susceptibility to the disease. Independent association could not be demonstrated for the SNPs at TNF- $\alpha-308$ and -857 position.

The TNF- $\alpha$ promoter polymorphism at position -238 is associated with a number of immune mediated disorders [25-29]. It is reported to be associated with disease severity in RA independent of the major HLA-DRB1 ${ }^{\star} 04$ risk loci [30]. The -238 GG genotype was reported to be associated with severe course of RA and poor response to combination DMARD therapy [13,31]. It was also found to be associated with a severe destructive disease course and younger age of onset and was thus suggested to be a potential predictive biomarker of destructive joint disease in RA [29]. In our study, we did not observe any correlation of this polymorphism with clinical or biological features of RA suggesting that this polymorphism does not act as a genetic modifier of the disease phenotype in South Indian Tamils.

The TNF- $\alpha-308$ is the most commonly investigated polymorphism in RA. It is reported to be a risk factor for RA in Chinese and Latin Americans but not in Caucasians [17]. It is also considered to influence disease severity $[12,31]$. In our study, the TNF- $\alpha-308$ SNP was the least polymorphic in both patients and controls. A vast majority of patients carried the common -308G allele (97.7\%). None of them had the homozygous -308 AA mutant genotype. The reported frequency of the -308 minor A allele varies among populations ranging from $3.3 \%$ in Japanese to $24 \%$ in Northern Sweden [32,33]. Similarly to the reported data, less than $2 \%$ individuals in our study had -238AA homozygous mutant genotype. This confirms the rarity of the -308 homozygous mutant genotype in South Indians besides other Asian 
Citation: Mariaselvam CM, Sofiane S, Boukouaci W, Fortier C, Charron D, et al. (2014) TNF alpha Promoter Polymorphism May Confer Susceptibility to Rheumatoid Arthritis and Influence TNF alpha Production but not the Clinical Phenotype and Treatment Response. J Mol Biomark Diagn 5: 206. doi:10.4172/2155-9929.1000206

Page 5 of 6

population-groups [14]. Such observations may, at least in part, explain ethnic variations in susceptibility and/or severity of RA.

Due to less polymorphic nature of TNF- $\alpha-308$ in our population, it is unlikely to be a susceptibility factor for RA or to influence disease phenotype. As described recently by Mekinian et al, it does not influence TNF- $\alpha$ production and hence may not play a significant role in response to therapy $[19,20,34]$.

In terms of functional significance the TNF- $\alpha$ promoter -308/-238 G-G diplotype was previously associated with low TNF- $\alpha$ production, whereas the TNF- $\alpha-308 \mathrm{~A}$ and $-238 \mathrm{~A}$ alleles were associated with high TNF- $\alpha$ production [35]. This apparent association may likely have been due to linkage disequilibrium with a proven functionally important SNP TNF- $\alpha-376$. Allele specific binding of the ubiquitous transcription factor OCT- 1 was demonstrated for the TNF- $\alpha-376$ and -857 SNPs [36]. In in-vitro cell proliferation studies, the TNF- $\alpha-857 \mathrm{~T}$ allele was reported to be associated with high TNF- $\alpha$ production [37], which is in agreement with the association herein described between TNF- $\alpha-857$ T allele and high serum levels of TNF- $\alpha$. Due to the rarity of -308 and -238 mutant alleles in our studied populations, the TNF- $\alpha$ -857 may primarily be responsible for transcriptional regulation of TNF- $\alpha$ production and its increased concentration at the site of synovial inflammation and in peripheral blood in RA patients.

There is evidence to suggest that patients with TNF- $\alpha$ gene polymorphism associated with low TNF- $\alpha$ production may respond well to anti TNF therapy [19]. Thus, TNF- $\alpha-857$ polymorphism may not only influence TNF- $\alpha$ production but also the response to treatment with anti-TNF biologicals. This polymorphism has the potential to become a useful genetic marker for predicting response to therapy in Asians. Due to cost constraints none of our patients were treated with anti-TNF agents. Hence, the influence of this promoter region polymorphism on treatment response could not be ascertained and warrants further investigation. Considering genetic heterogeneity of Indian population, the association of the TNF- $\alpha-238$ promoter polymorphism with RA in ethnic Tamil patients from South India as susceptibility marker for RA has to be taken with caution in the panIndian context as the gene-gene interaction between TNF- $\alpha$ promoter region and other HLA region genes especially HLA DRB1 shared epitope (SE) were not a part of our study. The influence of TNF promoter region polymorphism on TNF- $\alpha$ production and response to therapy with anti-TNF agents also needs further confirmation in Indian population.

In the present study the frequency of the RA risk haplotype TNF- $\alpha$ C-G-G $(-857,-308,-238)$ was found to be higher than that reported in other Asian and Caucasian populations [38-40]. This haplotype is part of the extended TNF haplotype G-T-C-C-G-G associated with susceptibility to sarcoidosis in Indians $[41,42]$. Previously, our group has reported that the ancestral TNF- $\alpha$ haplotype combination (C-GG/C-G-G), and not any particular SNP, was associated with response to TNF- $\alpha$ antagonists in RA in French Caucasians [39]. However, as our patients were not treated with TNF- $\alpha$ antagonists we could not establish such an association in the studied population.

Our study suggests that TNF- $\alpha-238$ promoter polymorphism and C-G-G haplotype may confer susceptibility to RA in ethnic Tamil population of South India. The -857 SNP of this gene is associated with high TNF- $\alpha$ production and may influence response to therapy with anti-TNF agents.

\section{Acknowledgements}

This work was supported by ICMR-INSERM joint collaborative research program between Department of Clinical Immunology, JIPMER, Pondicherry, INDIA and INSERM UMRS 940 (now U1160) and Assistance Publique des Hôpitaux de Paris (AP-HP), Hopital Saint Louis, Paris, FRANCE. (Grant No. INDO/FRC/526/2005-IHD and 50/8/2004-BMS)

\section{Author contributions}

VSN and RT are principal investigators, conceived and planned the study. CMM performed laboratory work with the assistance of SS and WB. VSN recruited the patients, collected, organized and interpreted the clinical data. DC, RK, VSN and RT co-coordinated the research and critically reviewed the manuscript. CMM, RK, VSN and RT wrote the paper. VSN takes primary responsibility for the paper.

\section{References}

1. Brennan FM, McInnes IB (2008) Evidence that cytokines play a role in rheumatoid arthritis. J Clin Invest 118: 3537-3545.

2. Feldmann M, Brennan FM, Maini RN (1996) Role of cytokines in rheumatoid arthritis. Annu Rev Immunol 14: 397-440.

3. McInnes IB, Schett G (2007) Cytokines in the pathogenesis of rheumatoid arthritis. Nat Rev Immunol 7: 429-442.

4. Keffer J, Probert L, Cazlaris H, Georgopoulos S, Kaslaris E, et al. (1991) Transgenic mice expressing human tumour necrosis factor: a predictive genetic model of arthritis. EMBO J 10: 4025-4031.

5. Feldmann M, Maini RN (2003) Lasker Clinical Medical Research Award. TNF defined as a therapeutic target for rheumatoid arthritis and other autoimmune diseases. Nat Med 9: 1245-1250.

6. Bayley JP, Ottenhoff TH, Verweij CL (2004) Is there a future for TNF promoter polymorphisms? Genes Immun 5: 315-329.

7. Elahi MM, Asotra K, Matata BM, Mastana SS (2009) Tumor necrosis factor alpha -308 gene locus promoter polymorphism: an analysis of association with health and disease. Biochim Biophys Acta 1792: 163-172.

8. Hajeer AH, Hutchinson IV (2001) Influence of TNFalpha gene polymorphisms on TNFalpha production and disease. Hum Immunol 62: 1191-1199.

9. Knight JC, Udalova I, Hill AV, Greenwood BM, Peshu N, et al. (1999) A polymorphism that affects OCT-1 binding to the TNF promoter region is associated with severe malaria. Nat Genet 22: 145-150.

10. Skoog T, van't Hooft FM, Kallin B, Jovinge S, Boquist S, et al. (1999) A common functional polymorphism (C-->A substitution at position -863) in the promoter region of the tumour necrosis factor-alpha (TNF-alpha) gene associated with reduced circulating levels of TNF-alpha. Hum Mol Genet 8: 1443-1449.

11. Wilson AG, Symons JA, McDowell TL, McDevitt HO, Duff GW (1997) Effects of a polymorphism in the human tumor necrosis factor alpha promoter on transcriptional activation. Proc Natl Acad Sci U S A 9: 3195-3199.

12. Boechat AL, Boechat Nde O, Ogusku MM, Alencar MR, Abensur Tda C, et al. (2013) The influence of a TNF gene polymorphism on the severity of rheumatoid arthritis in the Brazilian Amazon. Cytokine 6: 406-412.

13. Brinkman BM, Huizinga TW, Kurban SS, van der Velde EA, Schreuder GM, et al. (1997) Tumour necrosis factor alpha gene polymorphisms in rheumatoid arthritis: association with susceptibility to, or severity of, disease? Br J Rheumatol 36: 516-521.

14. Gambhir D, Lawrence A, Aggarwal A, Misra R, Mandal SK, et al. (2010) Association of tumor necrosis factor alpha and IL-10 promoter polymorphisms with rheumatoid arthritis in North Indian population. Rheumatol Int 30: 1211-1217. 
Citation: Mariaselvam CM, Sofiane S, Boukouaci W, Fortier C, Charron D, et al. (2014) TNF alpha Promoter Polymorphism May Confer Susceptibility to Rheumatoid Arthritis and Influence TNF alpha Production but not the Clinical Phenotype and Treatment Response. J Mol Biomark Diagn 5: 206. doi:10.4172/2155-9929.1000206

Page 6 of 6

15. Hirankarn N, Nakkuntod J, Duangchalermwong P, Deesomchok U, Charoenwongse $\mathrm{P}(2007)$ The association of $\mathrm{DRB} 1^{\star} 04$ share epitope alleles and tumor necrosis factor-alpha gene polymorphism $(-863)$ with susceptibility to rheumatoid arthritis in Thai. Rheumatol Int 28: 161-165.

16. Jiang Y, Zhang R, Zheng J, Liu P, Tang G, et al. (2012) Meta-analysis of 125 rheumatoid arthritis-related single nucleotide polymorphisms studied in the past two decades. PLoS One 7: e51571.

17. Lee YH, Ji JD, Song GG (2007) Tumor necrosis factor-alpha promoter -308 A/G polymorphism and rheumatoid arthritis susceptibility: a metaanalysis. J Rheumatol 34: 43-49.

18. Pawlik A, Florczak M, Ostanek L, Brzosko M, Brzosko I, et al. (2005) TNF-alpha -308 promoter polymorphism in patients with rheumatoid arthritis. Scand J Rheumatol 34: 22-26.

19. Lee YH, Ji JD, Bae SC, Song GG (2010) Associations between tumor necrosis factor-alpha (TNF-alpha) -308 and -238 G/A polymorphisms and shared epitope status and responsiveness to TNF-alpha blockers in rheumatoid arthritis: a metaanalysis update. J Rheumatol 37: 740-746.

20. Pavy S, Toonen EJ, Miceli-Richard C, Barrera P, van Riel PL, et al. (2010) Tumour necrosis factor alpha -308G->A polymorphism is not associated with response to TNFalpha blockers in Caucasian patients with rheumatoid arthritis: systematic review and meta-analysis. Ann Rheum Dis 69: 1022-1028.

21. Chopra A, Patil J, Billempelly V, Relwani J, Tandle HS, et al. (2001) Prevalence of rheumatic diseases in a rural population in western India: a WHO-ILAR COPCORD Study. J Assoc Physicians India 49: 240-246.

22. Malaviya AN, Kapoor SK, Singh RR, Kumar A, Pande I (1993) Prevalence of rheumatoid arthritis in the adult Indian population. Rheumatol Int 13: 131-134.

23. Aletaha D, Neogi T, Silman AJ, Funovits J, Felson DT, et al. (2010) 2010 Rheumatoid arthritis classification criteria: an American College of Rheumatology/European League Against Rheumatism collaborative initiative. Ann Rheum Dis 6: 2569-2581.

24. van Gestel AM, Prevoo ML, van 't Hof MA, van Rijswijk MH, van de Putte LB, et al. (1996) Development and validation of the European League Against Rheumatism response criteria for rheumatoid arthritis. Comparison with the preliminary American College of Rheumatology and the World Health Organization/International League Against Rheumatism Criteria. Arthritis Rheum 39: 34-40.

25. Laddha NC, Dwivedi M, Begum R (2012) Increased Tumor Necrosis Factor (TNF)-alpha and its promoter polymorphisms correlate with disease progression and higher susceptibility towards vitiligo. PloS one 7, e52298.

26. Mössner R, Kingo K, Kleensang A, Krüger U, König IR, et al. (2005) Association of TNF -238 and -308 promoter polymorphisms with psoriasis vulgaris and psoriatic arthritis but not with pustulosis palmoplantaris. J Invest Dermato 12: 282-284.

27. Schmeling H, Wagner U, Peterson A, Horneff G (2006) Tumor necrosis factor alpha promoter polymorphisms in patients with juvenile idiopathic arthritis. Clin Exp Rheumatol 2: 103-108.

28. Zou YF, Feng XL, Pan FM, Su H, Tao JH, et al. (2010) Meta-analysis of TNF-alpha promoter - 238A/G polymorphism and SLE susceptibility. Autoimmunity 43: 264-274.
29. Kaijzel EL, van Krugten MV, Brinkman BM, Huizinga TW, van der Straaten T, et al. (1998) Functional analysis of a human tumor necrosis factor alpha (TNF-alpha) promoter polymorphism related to joint damage in rheumatoid arthritis. Mol Med 4: 724-733.

30. Fabris M, Di Poi E, D'Elia A, Damante G, Sinigaglia L, et al. (2002) Tumor necrosis factor-alpha gene polymorphism in severe and mildmoderate rheumatoid arthritis. J Rheumatol 29: 29-33.

31. Toonen EJ, Barrera P, Fransen J, de Brouwer AP, Eijsbouts AM, et al. (2012) Meta-analysis identified the TNFA -308G > A promoter polymorphism as a risk factor for disease severity in patients with rheumatoid arthritis. Arthritis Res Ther 14: R264

32. Cvetkovic JT, Wallberg-Jonsson S, Stegmayr B, Rantapaa-Dahlqvist S, Lefvert AK (2002) Susceptibility for and clinical manifestations of rheumatoid arthritis are associated with polymorphisms of the TNFalpha, IL-1beta, and IL-1Ra genes. J Rheumatol 29: 212-219.

33. Seki N, Kamizono S, Yamada A, Higuchi T, Matsumoto H, et al. (1999) Polymorphisms in the 5 -flanking region of tumor necrosis factor-alpha gene in patients with rheumatoid arthritis. Tissue Antigens 54: 194-197.

34. Mekinian A, Tamouza R, Pavy S, Gestermann N, Ittah M, et al. (2011) Functional study of TNF- $\beta$ promoter polymorphisms: literature review and meta-analysis. Eur Cytokine Netw 22: 88-102.

35. Mira JP, Cariou A, Grall F, Delclaux C, Losser MR, et al. (1999) Association of TNF, a TNF-alpha promoter polymorphism, with septic shock susceptibility and mortality: a multicenter study. JAMA 28: 561-568.

36. Hohjoh H. Tokunaga K (2001) Allele-specific binding of the ubiquitous transcription factor OCT-1 to the functional single nucleotide polymorphism (SNP) sites in the tumor necrosis factor-alpha gene (TNFA) promoter. Genes Immun 2: 105-109.

37. Soga Y, Nishimura F, Ohyama H, Maeda H, Takashiba S, et al. (2003) Tumor necrosis factor-alpha gene (TNF-alpha) -1031/-86, -857 singlenucleotide polymorphisms (SNPs) are associated with severe adult periodontitis in Japanese. J Clin Periodontol 30: 524-531.

38. Kang CP, Lee KW, Yoo DH, Kang C, Bae SC (2005) The influence of a polymorphism at position -857 of the tumour necrosis factor alpha gene on clinical response to etanercept therapy in rheumatoid arthritis. Rheumatology (Oxford) 44: 547-552.

39. Miceli-Richard C, Comets E, Verstuyft C, Tamouza R, Loiseau P, et al. (2008) A single tumour necrosis factor haplotype influences the response to adalimumab in rheumatoid arthritis. Ann Rheum Dis 67: 478-484.

40. Park YJ, Park H, Park MH (2004) TNF-alpha promoter polymorphisms and extended HLA and TNF-alpha haplotypes in Koreans based on 100 families. Tissue Antigens 63: 75-79.

41. Sharma S, Ghosh B, Sharma SK (2008) Association of TNF polymorphisms with sarcoidosis, its prognosis and tumour necrosis factor (TNF)-alpha levels in Asian Indians. Clin Exp Immunol 151: 251-259.

42. Li S, Huang X, Zhong H, Chen Z, Peng Q, et al. (2013) Tumour necrosis factor alpha (TNF-ÎI) genetic polymorphisms and the risk of autoimmune liver disease: a meta-analysis. J Genet 92: 617-628. 